\begin{tabular}{lr}
\hline PRACE NAUKOWE UNIWERSYTETU EKONOMICZNEGO WE WROCŁAWIU \\
RESEARCH PAPERS OF WROCŁAW UNIVERSITY OF ECONOMICS & \begin{tabular}{rr}
$\mathbf{n r}$ 473 • 2017 \\
\hline Gospodarka turystyczna w regionie.
\end{tabular} \\
Przedsiębiorstwo. Samorzą. Współpraca & $\begin{array}{l}\text { ISSN 1899-3192 } \\
\text { e-ISSN 2392-0041 }\end{array}$
\end{tabular}

\author{
Agata Basińska-Zych \\ Wyższa Szkoła Bankowa w Poznaniu \\ e-mail: agata.basinska-zych@wsb.poznan.pl
}

\title{
Bernadeta Hołderna-Mielcarek
}

Akademia Wychowania Fizycznego w Poznaniu

e-mail: holderna-mielcarek@awf.poznan.pl

\section{WPLYW TURYSTYCZNO-REKREACYJNYCH ZACHOWAŃ MIESZKAŃCÓW NA ROZWÓJ INNOWACYJNEJ OFERTY METROPOLII NA PRZYKLADZIE POZNANIA ${ }^{1}$}

\section{THE IMPACT OF TOURIST AND RECREATIONAL BEHAVIORS OF CITY INHABITANTS ON THE DEVELOPMENT OF INNOVATIVE METROPOLIS OFFER ON THE EXAMPLE OF POZNAN AGGLOMERATION}

DOI: $10.15611 /$ pn.2017.473.03

JEL Classification: I12, O18, Z20, Z32.

\begin{abstract}
Streszczenie: Problematyka podjęta w artykule obejmuje rozpoznanie różnic w modelach oddziaływania czynników osobistych, takich jak wiek, płeć, etap życia, zawód, warunki ekonomiczne, oraz motywów podejmowania aktywności fizycznej na zachowania turystyczno-rekreacyjne mieszkańców metropolii Poznań. Pomiaru źródeł pierwotnych dokonano za pomocą ilościowych metod i technik badań (sondaż diagnostyczny, standaryzowany kwestionariusz ankietowy), którymi objęto 1584 pełnoletnich mieszkańców metropolii Poznań. Wyniki badań dowodzą, że czynniki osobiste, takie jak wiek, płeć, etap życia, zawód, warunki ekonomiczne, oraz motywy podejmowania aktywności rekreacyjnej różnicują zachowania turystyczno-rekreacyjne mieszkańców metropolii Poznań. Wyniki badania zostały wykorzystane w opracowaniu propozycji rozwoju innowacyjnej oferty turystycznej i rekreacyjnej miasta dla mieszkańców metropolii Poznań.
\end{abstract}

\footnotetext{
${ }^{1}$ Artykuł powstał na bazie badań naukowych finansowanych z projektu w ramach dotacji podmiotowej na utrzymanie potencjału badawczego ze środków MNiSW pt. Region metropolitarny jako przestrzeń penetracji rekreacyjnej na przykładzie aglomeracji Poznań, realizowanego w latach 2015-2016 pod kierunkiem dr Agaty Basińskiej-Zych w Wyższej Szkole Bankowej w Poznaniu (nr decyzji 27090/E534/S/2016).
} 
Słowa kluczowe: zachowania turystyczno-rekreacyjne, rekreacja, metropolia Poznań, oferta turystyczna, innowacje.

\begin{abstract}
Summary: Creating the innovative tourist and recreational offer of the city requires the recognition of consumer behaviors and identifying patterns/models of the interaction between the factors and the behaviors of buyers of a tourist and recreational offer. The article presents the empirical results of surveys conducted in the period from March to June 2016. among 1,584 residents of 22 municipalities as a part of the metropolitan area of Poznan. The main aim of the article is to identify the impact of personal factors such as age, gender, stage of life, occupation and economic conditions. Moreover, the second goal of the paper is to investigate the impact of psychological factors like the motives of physical activity conditioning tourist and recreational behaviors of residents of Poznan metropolis. Accordingly, the tourist and recreational behavior analysis and the identification of personal factors are the starting point to define the opportunities of the innovative offer of tourist and recreation development for the residents of the Metropolitan area of Poznan. The results of studies show that personal factors such as age, gender, stage of life, occupation, economic conditions and psychological factors like motives have an impact on the tourist and recreational behavior of the residents of the metropolis of Poznan.
\end{abstract}

Keywords: tourist and recreational behaviors, recreation, Poznan metropolis, tourist offer of the city, innovation.

\title{
1. Wstęp
}

W ostatnich dziesięcioleciach zauważa się wielki powrót masowej turystyki do miast [Zmyślony 2015, s. 6]. Proces ten zachodzi również w polskich aglomeracjach. Obserwuje się rosnące znaczenie turystyki miejskiej z wszystkimi jej odmianami, takimi jak m.in. turystyka kulturowa, aktywna, sportowa. Obszary metropolitalne ${ }^{2}$ poprzez swoje walory przyrodnicze $\mathrm{i}$ antropogeniczne, atrakcje i produkty turystyczne, odgrywają ważną rolę regionu turystycznego i rekreacyjnego. Warto podkreślić, iż coraz częściej są one kształtowane przez władze i społeczność lokalną [Kowalczyk 2004, s. 186; Rapacz 2001], stanowiąc rezultat świadomej polityki turystycznej i strategii rozwoju lokalnego. Wprowadzenie nowej funkcji ma zwykle przyczynić się do wzrostu konkurencyjności obszarów, a jednocześnie do zapewnienia mieszkańcom możliwości spędzania czasu wolnego. Nieraz funkcję turystyczną kształtuje wprowadzenie atrakcji sportowo-rekreacyjnych, służących początkowo mieszkańcom, które z czasem przyciągają odwiedzających spoza miejsca zamieszkania, w tym turystów. W takim wypadku rozwój funkcji rekreacyjnej prowadzi do ukształtowania funkcji turystycznej [Majewska 2012, s. 18]. Kreowanie oferty tu-

\footnotetext{
${ }^{2}$ Nie wypracowano dotąd jednej oficjalnej i umocowanej prawnie koncepcji delimitacji aglomeracji lub obszarów metropolitalnych, podobnie jak w literaturze przedmiotu termin aglomeracja miejska jest różnie rozumiany. Metropolie to miasta, które według różnych klasyfikacji liczą powyżej 500 tys. mieszkańców, stanowią spójny układ przestrzenno-strukturalny, będący efektem procesu koncentracji ludności i podmiotów gospodarczych; za: [Parysek 2008, s. 28-48].
} 
rystyczno-rekreacyjnej wymaga innowacyjnego podejścia w jej rozwoju, uwzględniającego modele zachowań mieszkańców i czynniki je determinujące. W literaturze przedmiotu występują różne koncepcje, definicje i klasyfikacje innowacji ${ }^{3}$. W opracowaniu przyjęte zostało podejście sektorowe Abernathy'ego i Clarka [Brzezińska-Wójcik 2012, s. 131] oraz wykorzystane dwie koncepcje, które pojawiły się na początku XXI w.: koncepcja innowacji otwartych (open innovations) i koncepcja UDI (user-driven innovation - consumer innovativeness) [Dziedzic i in. 2016, s. 27-28].

\section{Material i metody badań}

Zakres przestrzenny badań obejmuję metropolię Poznań w rozumieniu obszaru metropolitarnego miasta Poznań, 17 gmin powiatu poznańskiego oraz gmin Oborniki, Śrem, Szamotuły i Skoki, które należą do Stowarzyszenia Metropolia Poznań. Aglomeracja poznańska należy do grupy siedmiu najbardziej zurbanizowanych obszarów Polski, obok czterech aglomeracji: warszawskiej, krakowskiej, łódzkiej, wrocławskiej i dwóch konurbacji: górnośląskiej i trójmiejskiej. Ponadto aglomeracja poznańska z liczbą blisko 1023 tys. mieszkańców jest jednym z głównych elementów współczesnego układu osadniczego nie tylko w skali Polski, ale i Europy [Metropolia Poznań 2020, s. 19].

W badaniach zastosowano metodę sondażu diagnostycznego w oparciu o autorski kwestionariusz ankiety, składający się z 29 pytań z rozbudowaną częścią metryczkową. Pytania miały w większości charakter zamknięty i dotyczyły aktywności fizycznej i rekreacyjnej mieszkańców metropolii Poznań ${ }^{4}$. Badania ankietowe przeprowadzono od marca do czerwca 2016 na próbie 1584 mieszkańców metropolii Poznań przy pomocy 5 przeszkolonych ankieterów. Badania realizowano na terenie wszystkich 22 gmin metropolii Poznań, w różne dni tygodnia, o różnych porach dnia, przed obiektami rekreacyjno-sportowymi oraz w ogólnodostępnych miejscach rekreacji, czyli m.in. na szlakach turystycznych, w parkach czy placach zabaw. Dobór respondentów do badań ankietowych miał charakter kwotowo-proporcjonalny. Minimalna liczba ankiet została obliczona na podstawie poziomu ufności 95\%

\footnotetext{
${ }^{3}$ Autorzy przedstawiają pojęcia i typologie innowacji oraz wskazują wybrane aspekty wiążące się z problematyką innowacyjności, które obejmują m.in. czynniki determinujące rozprzestrzenianie się innowacji w turystyce [Januszewska 2009, s. 158-166], innowacje jako czynnik konkurencyjności i rozwoju [Roman 2014, s. 115-128], wybrane elementy innowacji i innowacyjności w rekreacji [Michałowski, Ziółkowski 2010, s. 47-58], analizę działań innowacyjnych branży turystycznej województwa lubelskiego w zakresie oferty turystyki aktywnej i kulturowej [Krukowska i in. 2013, s. 161-169], innowacyjność przedsiębiorstw turystycznych jako czynnik rozwoju regionu turystycznego [Januszewska, Nawrocka 2015], innowacje w turystyce miejskiej i determinanty ich rozwoju [Czernek 2014, s. 55-79].

${ }^{4} \mathrm{~W}$ pierwszej części kwestionariusza wykorzystano też Międzynarodowy Kwestionariusz Aktywności Fizycznej IPAQ w wersji krótkiej. Polską wersję kwestionariusza (krótką i długą), przygotowane zgodnie z zaleceniami Komitetu Naukowego IPAQ, opracowali Stupnicki i Biernat [Biernat i in. 2007, s. 47-54].
} 
$(\alpha=0,05)$ przy maksymalnym błędzie $\pm 5 \%(0,05)$ i wynosiła 1426 ankiet. Określając wielkość i strukturę próby badawczej mieszkańców metropolii Poznań, uwzględniono dane Urzędu Statystycznego w Poznaniu dotyczące stanu ludności w dniu 31.12.2015 r. w podziale na płeć, wiek w układzie gminnym [http://poznan.stat.gov. pl]. Ze względu na ograniczoną objętość w artykule skoncentrowano się na analizie wskaźników natężenia. W analizie wyników wykorzystano oprogramowanie SPSS, a w szczególności posiłkowano się testami statystycznymi: dla zmiennych ilościowych analizą istotności różnic między poszczególnymi średnimi na podstawie testu T-studenta, a dla zmiennych jakościowych porównano istotność różnic proporcji kolumnowych, wykorzystując testy Z. W przypadku zmiennych ilościowych, by wykazać istotność różnic przy podziale na więcej niż 2 grupy, wykonano jednoczynnikową analizę wariancji ANOVA oraz dla porównań wielokrotnych test NIR. Wyniki są oparte na testach dwustronnych, z poziomem istotności wynoszącym $\mathrm{p}<0,05$.

\section{Zachowania turystyczno-rekreacyjne mieszkańców metropolii Poznań}

\subsection{Charakterystyka respondentów}

W badaniach wzięło udział 1584 pełnoletnich mieszkańców metropolii Poznań, z czego większość stanowiły kobiety (51\%). Ankietowani zamieszkiwali 22 gminy należące do aglomeracji poznańskiej. Według struktury wieku większość respondentów była w wieku 50-64 lat (24\%), między 27 a 36 rokiem życia - 23\%, a 22\% ankietowanych miało 37-49 lat. Najmniej licznymi segmentami wiekowymi biorącymi udział w badaniach były osoby między 18 a 26 rokiem życia, stanowiące $12 \%$ badanych, oraz po 65 roku życia (18\%). Większość ankietowanych mieszkańców aglomeracji Poznań legitymowała się wykształceniem średnim - 40\% lub wyższym $-32 \%$, a średnio co piąty respondent miał wykształcenie zawodowe lub podstawowe (2\%). Wśród ankietowanych 13\% mieszkańców metropolii Poznań było osobami z niepełnosprawnością.

Prawie $65 \%$ badanych mieszkańców aglomeracji poznańskiej biorących udział w sondażu deklarowało co najmniej jedno dziecko, natomiast $35 \%$ było bezdzietnych. Spośród tych posiadających dzieci odpowiednio po $31 \%$ miało 1 dziecko lub 2-3 dzieci, a tylko $2 \%$ posiadało 4 lub więcej pociech.

Jeśli chodzi o status ekonomiczny, co trzeci badany deklarował średni dochód netto na członka w rodzinie w przedziale między 2001 a 3001 zł, a $31 \%$ między 1001 a 2000 zl. Najrzadziej reprezentowane były przedziały ankietowanych deklarujących do $1000 \mathrm{zł}$ na osobę w rodzinie (7\%) oraz powyżej 3000 zł na członka rodziny $(9 \%)$.

Wśród badanych mieszkańców aglomeracji poznańskiej dominowali pracownicy sektora prywatnego $(34 \%)$, emeryci i renciści $(22 \%)$ oraz pracownicy sektora publicznego (16\%). Natomiast tylko średnio co dziesiąty ankietowany był uczniem 
lub studentem, $8 \%$ badanych stanowili prywatni przedsiębiorcy, $4 \%$ bezrobotni, $2 \%$ rolnicy oraz inni bierni zawodowo, a $1 \%$ pracował w sektorze pozarządowym.

\subsection{Motywy i formy podejmowania aktywności rekreacyjnej mieszkańców metropolii Poznań}

Analiza wyników badania pozwala wyróżnić dwa główne motywy podejmowania aktywności rekreacyjnej przez mieszkańców metropolii Poznań, do których należą: wypoczynek i relaks $(39,1 \%)$ oraz poprawa sprawności fizycznej $(25,7 \%)$. Wymienione motywy podejmowania aktywności rekreacyjnej uznane zostały za najważniejsze przez wszystkich mieszkańców, bez względu na płeć, wiek, stan cywilny, wykształcenie. Wyniki badania pozwalają wyróżnić niektóre grupy mieszkańców, dla których motyw wypoczynku i relaksu ma ważniejsze znaczenie niż dla pozostałych; należą do nich: mieszkańcy wsi $(45,8 \%)$, mieszkańcy posiadający wykształcenie zawodowe $(44,3 \%)$, rolnicy $(57,1 \%)$, bezrobotni $(41,7 \%)$. Do wzrostu znaczenia motywu wypoczynku i relaksu ${ }^{5} \mathrm{w}$ podejmowaniu aktywności rekreacyjnej przyczynia się posiadanie takich dóbr materialnych, jak żaglówka, motorówka $(50,0 \%)$ i sprzęt myśliwski, wędkarski $(56,7 \%)$, posiadanie domu letniskowego $(45,3 \%)$, przyczepy kempingowej, kampera (43,8\%), namiotu (43,0\%). Można też wskazać grupy mieszkańców, dla których motyw poprawy sprawności fizycznej ${ }^{6}$ ma większe znaczenie w porównaniu z wcześniej wymienionymi, nawet dwu- do czterokrotnie. Dla przedstawicieli władz publicznych, wyższych urzędników i pracowników na stanowiskach kierowniczych poprawa sprawności fizycznej stanowi pierwszoplanowy motyw aktywności rekreacyjnej $(41,5 \%)$, dla prywatnych przedsiębiorców jest on równie ważny jak wypoczynek i relaks $(30,8 \%)$, dla mieszkańców posiadających 4 i więcej dzieci przewyższa prawie o 10 p.p. motyw wypoczynku i relaksu $(27,3 \%)$. Znaczenie tego motywu wzrasta także w przypadku mieszkańców o wyższych dochodach netto na członka rodziny. Analizując inne motywy podejmowania aktywności rekreacyjnej przez mieszkańców metropolii Poznań, można wyróżnić segmenty rynku rekreacyjnego, dla których ważniejsze niż dla pozostałych są następujące motywy: 1) poprawa stanu zdrowia: mieszkańcy o dochodach pow. $3000 \mathrm{zł}(12,3 \%)$, grupa wiekowa $65+(22,5 \%)$; 2$)$ spędzenie czasu z rodziną i ze znajomymi: rodziny wielodzietne pow. 4 dzieci $(27,3 \%)$, osoby bezrobotne (16,7\%), rolnicy, ogrodnicy, leśnicy i rybacy $(14,3)$, najstarsza grupa wiekowa $65+(9,7 \%)$; 3$)$ ładna sylwetka: bierni zawodowo $(22,2 \%)$, grupa wiekowa $18-26$ lat $(12,5 \%)$, uczniowie i studenci $(10,7 \%)$, mieszkańcy o dochodach pow. 3000 zł $(9,8 \%)$; 4) opóźnienie starzenia: rolnicy, ogrodnicy, leśnicy i rybacy $(28,6 \%)$.

Analizą objęte zostały także zachowania rekreacyjne dotyczące preferowanej

\footnotetext{
${ }^{5}$ Testy istotności różnic potwierdziły zróżnicowanie w zakresie wpływu następujących czynników: płeć ( $p<0,016)$, wiek $(\mathrm{p}<0,010)$, dochód netto na członka rodziny $(\mathrm{p}<0,013)$, liczba posiadanych dzieci $(\mathrm{p}<0,001)$ na wybór motywu podejmowania aktywności rekreacyjnej - wypoczynek i relaks.

${ }^{6}$ Testy istotności różnic wykazały zróżnicowanie w zakresie wpływu następujących zmiennych: wiek ( $\mathrm{p}<0,000)$, dochód netto na członka rodziny $(\mathrm{p}<0,000)$, liczba posiadanych dzieci $(\mathrm{p}<0,000)$ na wybór motywu podejmowania aktywności rekreacyjnej - poprawa sprawności fizycznej.
} 
formy aktywności rekreacyjnej. Ogólnie mieszkańcy metropolii Poznań preferują indywidualne formy rekreacji (70,6\%), jedynie 20,9\% deklaruje udział w zajęciach grupowych. Wyniki badania ukazują oddziaływanie czynników osobistych na wybór formy rekreacji ${ }^{7}$. Kobiety $(24,7 \%)$, a także mieszkańcy z wyższym wykształceniem $(22,5 \%)$, rodziny posiadające 4 i więcej dzieci $(18,2 \%)$, osoby o wyższych dochodach netto na członka rodziny (26,2\% pow. 3000 zł netto ) częściej uczestniczą w rekreacji grupowej. Na wzrost udziału w grupowych formach rekreacji wpływa posiadanie takich dóbr materialnych, jak: apartament, drugie mieszkanie $(35,7 \%)$, kajak, łódka, rower wodny $(27,8 \%)$. Wraz z wiekiem obniża się udział mieszkańców w grupowej formie rekreacji: 37-49 (13,8\%) i 50-64 (12,0\%).

Do trzech najczęściej podejmowanych aktywności ruchowych w miejscu zamieszkania należą: wędrówki piesze/spacery, które realizuje 53 na 100 osób; jazda na rowerze, którą wybiera 38 na 100 osób; pływanie, które preferuje 29 na 100 osób. Do aktywności podejmowanych w miejscu stałego zamieszkania przez co najmniej 10 na 100 osób należą: fitness (14 osób na 100), bieganie/jogging (14 na 100 osób), inne aktywności (10 na 100 osób), nordic walking (10 na 100 osób). Analiza zmiennych osobistych umożliwia sformułować wniosek, iż płeć różnicuje ${ }^{8}$ dwie najczęściej podejmowane przez mieszkańców aktywności ruchowe w miejscu stałego zamieszkania. Można też zauważyć różnice pomiędzy udziałem kobiet i mężczyzn w pozostałych formach aktywności. Do aktywności ruchowych, w których częściej uczestniczą kobiety, należą: wędrówki piesze/spacery, pływanie, zajęcia fitness, bieganie, nordic walking, aerobik, jazda na rolkach. Natomiast mężczyźni częściej podejmują: jazdę na rowerze, wędkarstwo, grę w tenisa oraz inne aktywności.

Ponadto zmienne osobiste, takie jak: wiek, wykształcenie, status zawodowy, stan cywilny, liczba dzieci w rodzinie, posiadanie dóbr materialnych, różnicują wzorce zachowań rekreacyjnych mieszkańców metropolii Poznań. Wyniki badania pozwalają wyróżnić dwa segmenty rynku rekreacyjnego ze względu na kryterium wieku: „młodsze” i „starsze grupy wiekowe”, które charakteryzuje różny udział w podejmowanych formach aktywności ruchowej. Młodsi mieszkańcy, do 35 roku życia, najczęściej podejmują w miejscu zamieszkania: jazdę na rowerze, wędrówki piesze/ spacery, udział w zajęciach fitness, bieganie/jogging, jazdę na rolkach. Do aktywności ruchowych, których udział wraz z wiekiem wzrasta, należą: wędrówki /spacery piesze, nordic walking, wędkarstwo. W przypadku dwóch najczęściej deklarowanych przez mieszkańców metropolii Poznań aktywności ruchowych, tj. wędrówek/ spacerów pieszych i jazdy na rowerze, wyniki badania pozwalają wnioskować, że występują przesłanki wskazujące na niewystępowanie związku pomiędzy podejmowanymi aktywnościami ruchowymi a poziomem dochodów. Natomiast pływanie częściej deklarują mieszkańcy o dochodach pow. 3000 zł.

7 Różnice istotne statystycznie wykryto dla czynników: wykształcenie $(\mathrm{p}<0,003)$, wiek $(p<0,006)$, płeć $(p<0,000)$, zawód $(p<0,000)$, dochód netto na członka w rodzinie $(p<0,000)$, posiadane dobra materialne $(\mathrm{p}<0,000)$.

${ }^{8}$ Wędrówki/spacery $(\mathrm{p}<0,002)$, jazda na rowerze $(\mathrm{p}<0,007)$. 


\subsection{Uczestnictwo $w$ imprezach sportowych i rekreacyjnych oraz wyjazdy turystyczne w celach aktywności rekreacyjnej mieszkańców metropolii Poznań}

Wyniki badań dotyczące uczestnictwa mieszkańców metropolii Poznań w imprezach rywalizacji sportowej wskazują, iż zaledwie ok. 20 na 100 osób uczestniczy w tego typu imprezach - jako widzowie, ale także jako aktywni uczestnicy. Największą popularnością wśród widzów cieszą się wydarzenia sportowe typu półmaratony (ok. 18 na 100 osób) i maratony (13 na 100 osób), ale także zawody sportowe (13,2 na 100 osób). Wśród deklarowanych dyscyplin wskazywano w większości imprezy biegowe typu półmaraton (ok. 15 na 100 osób) oraz maraton (13 na 100 osób). Rzadziej sygnalizowano udział w wydarzeniach w obszarze: pływania, nordic walking, jazdy na rolkach. Warto dodać, że ankietowani mieszkańcy deklarowali czynne uczestnictwo w imprezach biegowych (5 na 100 osób) oraz pływackich (1,5 na 100 osób).

Analiza wpływu zmiennych osobistych na uczestnictwo mieszkańców w imprezach sportowych upoważnia do sformułowania następujących wniosków:

1) częściej uczestnictwo bierne w imprezach sportowych typu półmaratony biegowe (20,6 na 100 osób) czy maratony biegowe (15,2 na 100 osób) deklarowali mężczyźni niż kobiety (11,6 na 100 osób oraz 10,2 na 100 osób), przeważnie w wieku 27-36 lat (łącznie 33,8 na 100 osób), 50-64 lat (łącznie 33,1 na 100 osób) lub 1826 lat (łącznie 28,6 na 100 osób), z wykształceniem zawodowym (łącznie 42 na 100 osób), posiadający często 4 i więcej dzieci, znajdujący się w przedziale dochodów netto na członka w rodzinie 1001-2000 zł (38,9 na 100 osób);

2) o uczestnictwie czynnym w półmaratonach lub maratonach biegowych częściej informowali również mężczyźni (8,4 na 100 osób) niż kobiety (5,6 na 100 osób), w wieku 27-36 lat (10,6 na 100 osób), z wykształceniem wyższym (9,1 na 100 osób), pracujący jako kierownicy, przedstawiciele władz publicznych, wyżsi urzędnicy (15,4 na 100 osób), technicy lub inny średni personel (11,6 na 100 osób) lub pracownicy biurowi (11,1 na 100 osób);

3) segmentem, który najrzadziej uczestniczy w imprezach sportowych jako widzowie lub zawodnicy, okazali się mieszkańcy w wieku powyżej 65 lat, emeryci, renciści lub inni bierni zawodowo.

Zbadano także uczestnictwo mieszkańców aglomeracji poznańskiej w imprezach o charakterze rekreacyjnym organizowanych $\mathrm{w}$ ich miejscu zamieszkania. Wyniki badań wskazują, iż niestety ponad $70 \%$ ankietowanych nie bierze udziału w wydarzeniach rekreacyjnych organizowanych w miejscu ich zamieszkania. Uczestniczący w nich badani preferują udział w festynach rekreacyjnych (41,5\%), rajdach pieszych $(24,5 \%)$ oraz rowerowych $(19,9 \%)$, a także grach miejskich $(16,2 \%)$. Zdecydowanie najrzadziej respondenci brali udział w questingu $(1,5 \%)$, geocachingu $(4,8 \%)$, street workout lub biegach na orientację $(5,1 \%)$ czy spływach kajakowych $(6,5 \%)$. Warto podkreślić, iż choć te formy są jeszcze stosunkowo rzadziej wybierane przez mieszkańców metropolii Poznań, to ze względu na efekt tzw. nowości preferowane 
były przez młodszych ankietowanych. W zakresie innych czynników osobistych nie potwierdzono istotnego zróżnicowania statystycznego.

Zachowania rekreacyjno-turystyczne obejmują także wyjazdy turystyczne mieszkańców aglomeracji poznańskiej. Ze względu na specyfikę badań ankietowani zostali poproszeni o odpowiedź na pytanie, czy wyjeżdżają turystycznie w celach aktywności fizycznej w obrębie metropolii Poznań. Blisko 80\% ankietowanych przyznało, że nie wyjeżdża w tych celach, natomiast $18,7 \%$ deklarowało takie wyjazdy. Najbardziej aktywni w tym zakresie okazali się mieszkańcy w wieku 18-26 lat $(25,1 \%)$ oraz $27-36$ lat $(28 \%)$, z wykształceniem wyższym $28,6 \%$, pracownicy sektora pozarządowego lub prywatni przedsiębiorcy, najczęściej bezdzietni, funkcjonujący z związkach partnerskich, konkubinatach, deklarujący dochód netto na członka rodziny w przedziale powyżej 3000 zł na osobę (31,3\%) lub 2001-3000 zł (22,5\%).

Testy istotności różnic statystycznych wykazały, że wiek, wykształcenie, status zawodowy, stan cywilny, wielkość rodziny oraz dochód różnicują zachowania turystyczne mieszkańców aglomeracji poznańskiej w formie wyjazdów o charakterze aktywnym ${ }^{9}$. Warto podkreślić, iż aktywny i zdrowy styl życia, obejmujący nie tylko uczestnictwo w rekreacji codziennej, ale będący wyrazem preferencji dotyczących aktywności podczas wyjazdów turystycznych, jest wybierany często przez mieszkańców miast oraz obszarów podmiejskich. Chętniej z wyjazdów tego typu korzystali mężczyźni (72,5 na 100 osób) niż kobiety (58,5 na 100 osób), w wieku 26-49 lat, pracownicy sektora prywatnego lub przedsiębiorcy o wyższym przedziale dochodów.

Ponadto prawie 65 na 100 ankietowanych deklarowało, iż wyjeżdżało w celach podejmowania aktywności rekreacyjnej na okres co najmniej 1 dnia w 2015 r. Natomiast dla prawie 28 na 100 osób wyjazdy te trwały od 2 do 4 dni z noclegiem, tylko dla 8 na 100 osób wyjazdy trwały ponad 5 dni. Wyniki te wskazują, iż w obrębie metropolii Poznań mieszkańcy preferują wypoczynek aktywny o charakterze krótkotrwałym lub weekendowym. Na ten cel ankietowani przeznaczyli w $2015 \mathrm{r}$. średnio $788 \mathrm{z}^{10}{ }^{10}$, przy czym wyższe kwoty deklarowali mężczyźni w wieku 37-49 lat $(956,5 \mathrm{zł})^{11}$ o dochodach powyżej $3000 \mathrm{zł}(1323,5 \mathrm{zl})^{12}$.

Warto podkreślić, iż ogólnie mieszkańcy metropolii Poznań oceniają ofertę sportowo-rekreacyjną dostępną w miejscu stałego zamieszkania dobrze. Co drugi mieszkaniec jest tego zdania. Średnio ofertę oceniał co piąty badany mieszkaniec, a dla $14,6 \%$ respondentów ocena ta była nawet bardzo dobra. Łącznie tylko 5\% badanych oceniło ofertę rekreacyjno-sportową miejsca zamieszkania źle lub bardzo źle.

\footnotetext{
${ }^{9}$ Różnice istotne statystycznie potwierdzono dla czynników: wykształcenie $(\mathrm{p}<0,000)$, wiek $(\mathrm{p}<0,000)$, zawód $(\mathrm{p}<0,000)$, dochód netto na członka w rodzinie $(\mathrm{p}<0,000)$, liczba posiadanych dzieci $(\mathrm{p}<0,000)$.

${ }^{10}$ Odchylenie standardowe $\sigma=748,5$.

${ }^{11}$ Odchylenie standardowe $\sigma=839,5$.

${ }^{12}$ Odchylenie standardowe $\sigma=1015,0$.
} 


\section{Kształtowanie innowacyjnej oferty turystycznej i rekreacyjnej dla mieszkańców metropolii Poznań}

Wyniki badania stanowią podstawę określenia obszarów i działań w zakresie rozwoju innowacyjnej oferty turystycznej i rekreacyjnej miasta skierowanej do mieszkańców metropolii Poznań. Z badań wynika, iż duży potencjał rozwojowy ma turystyka aktywna oraz sportowa. Istnieje duże zapotrzebowanie na formy rekreacji oparte na zróżnicowanych formach aktywności fizycznej. Z produktów tego typu mogą korzystać w pierwszej kolejności mieszkańcy gmin należących do obszaru metropolitarnego, ale także odwiedzający i turyści. Nawiązując do założeń wybranych koncepcji innowacji i ich klasyfikacji, kształtowanie oferty turystycznej i rekreacyjnej może obejmować wprowadzanie nowych lub zmiany w dotychczasowych ofertach, podnoszenie jakości i efektywności istniejącej oraz rozwój nowej, innowacyjnej infrastruktury turystyczno-rekreacyjnej, a także kreowanie popytu na nowe usługi i wydarzenia rekreacyjne. W kontekście dobrej oceny infrastruktury sportowo-rekreacyjnej metropolii Poznań warto podkreślić rolę innowacji regularnych, których głównym założeniem jest wprowadzanie innowacyjnych rozwiązań przyczyniających się do ciągłego podnoszenia standardu obiektów i urządzeń infrastruktury turystyczno-rekreacyjnej.

Zgodnie z założeniami koncepcji UDI, rozpoznanie zachowań turystyczno-rekreacyjnych mieszkańców metropolii Poznań stwarza możliwość ich uczestniczenia w procesie innowacyjnym oraz wykorzystanie zidentyfikowanych motywów i zachowań w określeniu nowych możliwości rozwoju oferty turystyczno-rekreacyjnej metropolii Poznań. Wyniki badania sugerują kształtowanie oferty zorientowanej na wyodrębnione grupy odbiorców. Innowacyjne rozwiązania produktowe mogą polegać na projektowaniu doświadczeń związanych z głównymi motywami podejmowania aktywności rekreacyjnej i dotyczyć: 1) doświadczeń zorientowanych na fitness, wellness, które są związane z takimi atrybutami, jak: podjąć jakieś działanie dla zdrowia, poczuć dobre samopoczucie, zrobić coś dla ciała i figury; 2) doznań związanych z takimi kompetencjami, jak: wytrwałość, przezwyciężanie „samego siebie”, poczucie radości i zadowolenia z dobrego wyniku, uczucie doskonalenia własnej fizycznej wydajności, podziwianie przez innych (,,prezentacja wydajności”); 3) doświadczeń wspierających socjalne przeżycia, których atrybutami są: uczucie możliwości wspólnego spędzenia czasu wolnego, spotkania z rodziną i przyjaciółmi, uczucie możliwości wzajemnego wsparcia.

Ogólnie można uznać, że w metropolii Poznań duży potencjał rozwoju innowacyjnych produktów stanowią: rynek wypoczynkowy oraz zorientowany na poprawę sprawności fizycznej. W aspekcie preferowanych form aktywności obszarami rozwoju innowacyjnych produktów rekreacyjno-turystycznych są rekreacja piesza, rowerowa oraz w pływanie rekreacyjne. Istniejąca oferta w tym zakresie obejmuje szlaki turystyczne piesze, rowerowe oraz pływalnie kryte i otwarte, a także strzeżone kąpieliska. Do innowacyjnych produktów należy zaliczyć przebiegający na 
terenie metropolii Poznań System Szlaków Rowerowych oraz pierwszy w Polsce system śladów GPS wszystkich tras rowerowych należących do Wielkopolskiego Systemu Szlaków Rowerowych - łącznie ok. 1500 km [http://www.umww.pl/departamenty_departament-sportu-i-turystyki_wielkopolski-system-szlakow-rowerowych]. Ważnym ogniwem promocji rekreacji rowerowej jest także Poznański Rower Miejski, który skupia obecnie 88 stacji i 923 rowery, stając się 4. pod względem wielkości systemem rowerowym w kraju [https://nextbike.pl/miasta/poznanski-rower-miejski/english-o-prm/]. Interesującą koncepcją Departamentu Sportu i Turystyki Urzędu Marszałkowskiego w Poznaniu w zakresie rozwoju turystyki pieszej jest opracowanie Wielkopolskiego Systemu Szlaków Pieszych jako kompletnego produktu turystycznego [http://www.umww.pl/departamenty_departament-sportu-i-turystyki_wielkopolski-system-szlakow-pieszych]. Dużym potencjałem rozwoju charakteryzuje się indywidualny rynek rekreacyjny. Indywidualne formy rekreacji oddziałują na kreowanie elastycznych produktów rekreacyjnych i zindywidualizowanych programów rekreacyjnych.

Przesłanką implementacji założeń koncepcji innowacji otwartych w sektorze turystyki i rekreacji jest duże zróżnicowanie instytucjonalne, infrastrukturalne i przestrzenne podmiotów zaangażowanych $\mathrm{w}$ organizację i świadczenie usług turystyczno-rekreacyjnych. Stwarza to konieczność poszukiwania skutecznych i efektywnych rozwiązań w obszarze koordynacji i zarządzania oraz identyfikacji kluczowych kompetencji partnerów w kreowaniu uzupełniającej się innowacyjnej oferty turystyczno-rekreacyjnej. Rozwój metropolitalnej oferty turystycznej i rekreacyjnej mogą wspomagać innowacje niszowe, polegające na łączeniu już istniejących produktów i rozwiązań poprzez podejmowanie współpracy z podmiotami z i spoza sektora turystyki i rekreacji.

\section{Zakończenie}

Na podstawie wyników przeprowadzonego badania można sądzić, że analizowane takie zmienne, jak: motywy podejmowania aktywności rekreacyjnej, rodzaje rekreacji, uczestnictwo w formach rekreacji w miejscu zamieszkania oraz imprezach sportowych, rekreacyjnych, a także wyjazdach o charakterze aktywności ruchowej charakteryzują wzorce zachowań turystyczno-rekreacyjnych mieszkańców metropolii Poznań. Umożliwiają także sformułowanie wniosku, iż analiza wpływu zmiennych osobistych oraz motywów podejmowania aktywności fizycznej na zachowania turystyczno-rekreacyjne mieszkańców metropolii Poznań może wspierać projektowanie innowacyjnych produktów skierowanych do wybranych grup mieszkańców.

Zdaniem autorek warto byłoby wzmocnić działania w zakresie kreowania oraz promowania ofert turystyczno-rekreacyjnych opartych na aktywności fizycznej. Wydaje się, że potencjał rekreacyjny metropolii Poznań jest jeszcze w tym zakresie w niewystarczającym stopniu wykorzystany. 


\section{Literatura}

Biernat E., Stupnicki R., Gajewski A.K., 2007, Międzynarodowy Kwestionariusz Aktywności Fizycznej (IPAQ) - wersja polska, Wychowanie Fizyczne i Sport, nr 51, s. 47-54.

Brzezińska-Wójcik T., 2012, Produkty geoturystyczne w województwie lubelskim jako przykład działań innowacyjnych, poszerzajacych dotychczasowa oferte turystyczna regionu, [w:] Jegorow D., Niedużak A. (red.), Wplyw sektora $B+R$ na wzrost konkurencyjności polskiej gospodarki poprzez rozwój innowacji, t. 1, Chełmskie Stowarzyszenie Rozwoju Społeczno-Gospodarczego CIVIS, Chełm.

Czernek K., 2014, Innowacje $w$ turystyce miejskiej $i$ determinanty ich rozwoju, Studia Oeconomica Posnaniensia, vol. 2, no. 3 (264), s. 55-79.

Dziedzic E., Szymańska E., Zawistowska H., Heliński W., Migdal M., 2016, Innowacyjność w turystyce, poradnik dla przygotowujacych, oceniajacych i realizujacych projekty innowacyjne i proinnowacyjne z zakresu turystyki, Ministerstwo Sportu i Turystyki, Warszawa, Poznań, Szczecin, Forum Turystyki Regionów, s. 27-28.

https://nextbike.pl/miasta/poznanski-rower-miejski/english-o-prm/ (15.02.17).

http://poznan.stat.gov.pl (15.02.2017).

http://www.umww.pl/departamenty_departament-sportu-i-turystyki_wielkopolski-system-szlakow-pieszych (15.02.2017).

http://www.umww.pl/departamenty_departament-sportu-i-turystyki_wielkopolski-system-szlakow-rowerowych (15.02.2017).

Januszewska M., 2009, Przestanki kreowania innowacji w turystyce na szczeblu regionu, nr 46: Gospodarka lokalna i regionalna w teorii i praktyce, Prace Naukowe Uniwersytetu Ekonomicznego we Wrocławiu, s. 158-166.

Januszewska M., Nawrocka E., 2015, Innowacyjność przedsiębiorstw turystycznych jako czynnik rozwoju regionu turystycznego, Problemy rozwoju regionalnego i lokalnego, Prace Naukowe Uniwersytetu Ekonomicznego we Wrocławiu, nr 393, Wrocław, s. 111-119.

Kowalczyk A., 2004, Koncepcja zależności od ścieżki (path dependency) w badaniach wptywu turystyki na rozwój regionalny i lokalny, Zeszyty Naukowe WSG w Bydgoszczy, t. 1, Turystyka i Rekreacja, nr 1, s. 179-194.

Majewska J., 2012, Rola samorzadu terytorialnego w ksztaltowaniu funkcji turystycznej gminy, Wydawnictwo UEP, Poznań.

Metropolia Poznań 2020, Strategia rozwoju aglomeracji Poznań, Centrum Badań Metropolitarnych, marzec 2011, Poznań, http://metropolia2020.poznan.pl/tresc-dokumentu (15.02.2017).

Michałowski K., Ziółkowski R., 2010, Zagadnienia innowacji i innowacyjności w turystyce i rekreacji, Zeszyty Naukowe Uniwersytetu Szczecińskiego. Ekonomiczne Problemy Turystyki, nr 13, s. 47-58.

Krukowska R., Skowronek E., Tucki A., 2013, Działania innowacyjne w branży turystycznej województwa lubelskiego w zakresie rozwoju oferty turystycznej, [w:] Gospodarka turystyczna w regionie. Wybrane problemy funkcjonowania regionów, gmin i przedsiębiorstw turystycznych, Prace naukowe Uniwersytetu Ekonomicznego we Wrocławiu, nr 207 (303), Wrocław, s. 161-169.

Parysek J., 2008, Aglomeracje miejskie w Polsce oraz problemy ich funkcjonowania i rozwoju, Bogucki Wydawnictwo Naukowe, Poznań, s. 28-48.

Roman M., 2014, Znaczenie innowacji w funkcjonowaniu sektora turystycznego - podejście teoretyczne i praktyczne, Zeszyty Naukowe Uniwersytetu Szczecińskiego. Ekonomiczne Problemy Turystyki, nr 1 (25), Podstawy funkcjonowania rynku turystycznego, s. 115-128.

Stan turystyki w Metropolii Poznań w latach 2013-2015, Raport na podstawie danych zebranych w ramach Poznańskiego Barometru Turystycznego, Poznańska Lokalna Organizacja Turystyczna, Poznań, https://drive.google.com/file/d/0BxquD9S_AjTmNFRLTXcta3V1WWc/view (15.02.2017).

Zmyślony P., 2015, Funkcja turystyczna w procesie internacjonalizacji miast, Wydawnictwo Proksenia, Kraków. 